\title{
Microfiltration of wheat starch suspensions using multichannel ceramic membrane
}

\author{
Bojana B. Ikonić ${ }^{1}$, Zoltan Z. Zavargo ${ }^{1}$, Aleksandar I. Jokić ${ }^{1}$, Zita I. Šereš ${ }^{1}$, Gyula N. Vatai ${ }^{2}$, \\ Mihailo B. Peruničić ${ }^{1}$ \\ ${ }^{1}$ Faculty of Technology, University of Novi Sad, Novi Sad, Serbia \\ ${ }^{2}$ Faculty of Food Science, Corvinus University of Budapest, Budapest, Hungary
}

\begin{abstract}
This work investigates the influence of different process parameters such as transmembrane pressure, flow rate and concentration of wheat starch suspension on the average permeate flux and permeate flux decline. The membrane used in all the experiments was 19 channels ceramic membrane with $0.2 \mu \mathrm{m}$ pore size. Experimental results were analyzed using response surface methodology. It was observed that the significant average permeate flux enhancement of $200 \%$ was achieved by the increase of the transmembrane pressure, while the increase of flow rate and concentration affected the increase in average permeate flux in the range of $40-100 \%$. Permeate flux decline was almost independent of the transmembrane pressure, but the increase of the flow rate, as well as the decrease of the concentration led to a decrease of permeate flux decline in the range of $20-50 \%$.
\end{abstract}

Keywords: Cross-flow microfiltration • Starch suspension • Full factorial design • Response surface methodology

SCIENTIFIC PAPER

UDC 664.231:66.067.1:66.03

Hem. Ind. 65 (2) 131-138 (2011)

doi: 10.2298/HEMIND101129074I

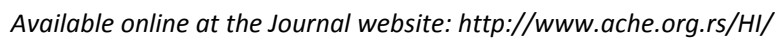

Membrane technology is a method for recovering processing solids and treat water for recycling in many food processing industries. The starch processing industry has increasing needs for higher value and maximum yields from every facility, due to more restrictive environmental regulations and increasing landfill and waste treatment costs. Application of membrane technology has several advantages for the starch processing Industry. Waste treatment costs could be reduced by using membranes to recover solids from a process stream that would otherwise enter the wastewater treatment facility $[1,2]$. Microfiltration and ultrafiltration are the most common membrane processes applied in wastewater treatment from starch processing industry and their applications, especially cross-flow microfiltration (CMF), are increasing rapidly. Microfiltration is a pressure-dependent process, which is usually used to remove particles in the range of $0.1-10 \mu \mathrm{m}$ from a suspension. The cross-flow microfiltration is influenced by a great number of parameters, e.g., cross-flow velocity, transmembrane pressure, size distribution of the suspended particles, particle form, agglomeration behavior and surface effects of the particles etc. A lot of models have been developed to describe the processes of the CMF, but only a few are sufficient to describe the real processes and explain the different experimental and practical results. Models for the description of the

Correspondence: B.B. Ikonić, Faculty of Technology, University of Novi Sad, Bulevar Cara Lazara 1, 21000 Novi Sad, Serbia.

E-mail: prodanic@tf.uns.ac.rs

Paper received: 29 November, 2010

Paper accepted: 13 December, 2010
CMF can be distinguished into empirical and physical models. The empirical consideration is useful in practice, but is not helpful for understanding the processes of cross-flow filtration [3].

There are only a few papers that deal with the application of membrane filtration for purification of wastewater from starch processing industry or for filtration of starch suspensions. Shukla et al. [4] considered the use of a tubular stainless steel-titania composite membrane with cornstarch suspensions, for possibly augmenting or replacing hydrocyclones, or centrifuges, for concentration and purification of starch. Experiments were conducted either in the total recycle mode or in the feed-and-bleed mode and concentrations of suspension were 1 or $4.7 \%(\mathrm{w} / \mathrm{w})$. From the wastewater treatment aspect, the best solution is precipitation of wastewater from starch production process, and after that, the use of membrane separation. Direct microfiltration of wastewater is not desirable from an economical aspect. After 2-4 $\mathrm{h}$ of precipitation, starch concentration of wastewater was about $1 \%(w / v)$. In that case, experiments should be conducted in retentate recycle mode. Hinkova et al. [5] examined ultrafiltration of amaranth suspension (containing 3\% of starch and maximum $3 \%$ of proteins) using multi channel inorganic membrane. They achieved VCF of 5 after 120 min of filtration, and permeate flux was very low in order to comply with the possible industrial application, although the membrane fouling was not so rapid. They also proposed further test with higher pressure (higher than 1.5 bar) or temperatures $\left(40^{\circ} \mathrm{C}\right)$. Testing at higher temperatures is not useful because temperatures of 
wastewater are about $22{ }^{\circ} \mathrm{C}$. Cancino et al. [6] examined the possibilities of microfiltration and reverse osmosis as a suitable treatment for wastewater from corn starch and biochemical oxygen demand (BOD) was the most important parameter for comparing efficiency of each step.

Response surface methodology (RSM) is a statistical method of data analysis that allows a better understanding of a process than the conventional methods of experimentation, because it is able to predict how the inputs affect the outputs in a complex process where different factors can interact among themselves. All the coefficients of the different polynomial equations were tested for significance with an analysis of variance (ANOVA) [7].

In the present work, an effort has been made to apply full factorial design (FFD) of experiments coupled with response surface methodology in order to investigate the effects of the process variables (transmembrane pressure, retentate flow rate and concentration) on the permeate flux for the microfiltration of model starch suspensions. Chosen concentrations were in the range of concentration of wastewater, from starch industry, after 2-4 h of precipitation. Experiments were conducted in retentate recycle mode, while permeate was removed from the system. The main reason for this type of investigation lied in the fact that large amounts of starch are present in wastewaters from starch industry and that is a substantial problem from an economic and environmental aspect. As a result, starch from wastewater can be regenerated and used.

\section{MATERIAL AND METHODS}

Starch suspensions for all experiments were made using dry wheat starch, A-type particles in range from 2 to $20 \mu \mathrm{m}$ (,Fidelinka-Skrob“, Subotica, Serbia) and distilled water.

The experiments were carried out using a conventional cross-flow microfiltration unit at Corvinus University, Budapest (Figure 1).

The feed was circulated by a centrifugal pump (Grundfos, Germany). The microfiltration was proceeded in the retentate recycling mode while the permeate was collected in the vessel until the required concentration was obtained. The transmembrane pressure difference was adjusted by the regulation valve. The inlet and outlet pressures of the membrane module were measured by two pressure gauges. The average of these two pressure values gave the value of transmembrane pressure as the outside of the membrane was vented to the atmosphere. The feed flow rate was regulated by a valve and measured with a rotameter. The multichannel (19 channels) $\alpha-\mathrm{Al}_{2} \mathrm{O}_{3}$ membrane used had a nominal pore size $0.2 \mu \mathrm{m}$ (Pall, USA) with the length of $837 \mathrm{~mm}$. The pore diameter was $2.5 \mathrm{~mm}$ and membrane diameter was $21 \mathrm{~mm}$. The useful membrane surface was $0.125 \mathrm{~m}^{2}$. This membrane was chosen to get a total particle rejection and thus to prevent pore blocking and adsorption.

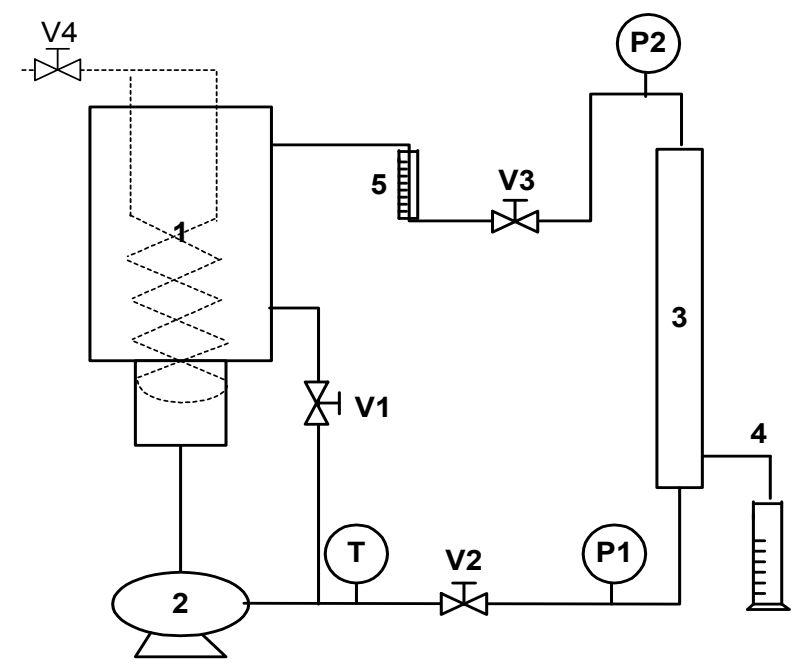

Figure 1. Schematic representation of experimental set-up for cross-flow microfiltration; 1 -feed tank with heat exchange, 2-pump, 3-membrane, 4-permeate outlet, 5-rotameter, $T$ - thermometer, $P 1$ and $P 2$ - manometers, V1, V2, V3 and $\mathrm{V} 4$ - valves.

The membrane was cleaned before each experiment with $2 \%$ solution of $\mathrm{NaOH}$ and $1.5 \%$ solution of $\mathrm{NaClO}$. The effectiveness in membrane cleaning was assessed by examining the water flux recovery. The cleaning procedure was repeated until the $95 \%$ of original water flux was restored.

The initial permeate flux was calculated from the amount of permeate collected for the first $10 \mathrm{~s}$, which was the time interval necessary to adjust a required transmembrane pressure and flow rate, and after that, the permeate flux was calculated from the time needed for the collection of $200 \mathrm{~mL}$ of permeate. All experiments were carried out at room temperature (22-25 $\left.{ }^{\circ} \mathrm{C}\right)$. Constant temperature of the feed suspension was achieved using spiral pipes immersed in the feed tank. Through these pipes, cold water was run, adjusting the flow with a regulation valve. All measurements in this study were carried out in triplicate and the results were averaged.

Volumetric concentration factor (VCF) during concentration of the starch suspension was determined as the ratio of feed volume at the beginning of operation, $V_{0}$, to retentate volume, $V_{R}$ in time $t$ :

$V C F=\frac{V_{0}}{V_{R}}$

The initial volume of wheat starch suspension was $12 \mathrm{~L}$ and it was microfiltrated until the volumetric concentration factor reached the value of 3 , i.e., $V_{R}=4 \mathrm{~L}$. 
The initial volume of suspension and VCF depended on the characteristics of the apparatus, i.e., feed tank volume and amount of retentate which can remain at the end of the process.

The operational hydrodynamic conditions were planned according to full factorial design (FFD), and permeate flux versus time was determined according to planned conditions [8]. Three independent variables, namely transmembrane pressure, $x_{1}$, retentate flow rate, $x_{2}$, and suspension concentration, $x_{3}$, were chosen and each independent variable had 3 levels. A total of 10 different combinations (including two replicates of the centre point) were chosen in random order [9].

The influences of transmembrane pressure (TMP), flow rate and concentration on the variation of permeate flux with time were analyzed by means of a statistical multifactorial analysis of experimental data. Experimental data can be employed to evaluate the regression coefficients of a polynomial equation that correlates a dependent variable with several independent variables. These regression coefficients can give information not only about the influence of the individual factors, but also about the effects among them:

$Y=b_{0}+\sum b_{i} x_{i}+\sum b_{i j} x_{i} x_{j}$

where $b_{0}$ represents intercept (constant), $b_{i}$ the linear and $b_{i j}$ the interaction effect of the factors; $Y$ represents response.

The adequacy of the model was evaluated by the coefficient of determination, $R^{2}$, and model $p$-value. The significance of regression coefficients was assessed by $p$-values at the 0.05 significance level. Statistical analysis was performed using Statistica 9 software. Plotting responses as a function of two factors drew response surface plots; the third factor was set to its medium value.

The first considered response was the average permeate flux calculated by integration of $J(t)$ from $t_{1}$ to $t_{n}$ which was determined as time needed to reach defined value of VCF [8]:
$J=\frac{1}{t_{n}} \int_{t_{1}}^{t_{n}} J(t) d t$

where $J(t)$ is the regression function of permeate flux determined by regression analysis.

The second response was chosen to anticipate the intensity of fouling phenomena. In this respect the permeate flux decline (FD) variable could be used given by the following relationship [8]:

$F D=\frac{J_{1}-J_{n}}{J_{1}}$

where $J_{1}$ is the initial permeate flux measured at the initial moment $t_{1}$, and $J_{n}$ is the final permeate flux measured at the final moment $t_{n}$ of the experiment.

\section{RESULTS AND DISCUSSION}

Measurements of dry matter in the permeate indicated that the solid phase was almost completely removed. Retention of starch particles on the membrane was from 99 to $99.9 \%$. The regression analysis was employed in order to find adequate regression models for fitting the experimental data of permeate flux decline. It was found that experimental data (permeate flux ( $L$ $\mathrm{m}^{-2} \mathrm{~h}^{-1}$ ) versus time (s)) are fitted well by the nonlinear regression equation of type:

$J(t)=a_{0}+a_{1} t+a_{2} \sqrt{t}+a_{3} t^{-1}+a_{4} t^{2}$

The values of the regression coefficients are reported in Table 1 and were computed by means of least square method using the Statistica 9 program.

The results of the statistical analysis according to the experimental plan are presented in Table 2 . The coefficients in Table 2 are related to actual variables.

The ANOVA results are reported in Table 3 for modeled responses. For ANOVA table the calculated F-value is greater than the tabulated one, thus the model is validated from a statistical standpoint considering good predictors for the experimental data. Relatively high

Table 1. Regression models for permeate flux decline

\begin{tabular}{lcc}
\hline Serial number & Regression equation for permeate flux decline & $R^{2}$ \\
\hline 1 & $J(t)=634.053+0.177 t-19.388 \sqrt{t}+359.122 t^{-1}-0.160 \times 10^{-4} t^{2}$ & 0.9967 \\
2 & $J(t)=162.854-0.024 t-2.005 \sqrt{t}-140.800 t^{-1}+0.753 \times 10^{-5} t^{2}$ & 0.9963 \\
3 & $J(t)=590.238+0.165 t-23.766 \sqrt{t}+616.487 t^{-1}+0.679 \times 10^{-4} t^{2}$ & 0.9937 \\
4 & $J(t)=108.115-0.006 t-1.165 \sqrt{t}+249.462 t^{-1}+0.179 \times 10^{-5} t^{2}$ & 0.9944 \\
5 & $J(t)=507.218-0.332 t+2.153 \sqrt{t}+1280.240 t^{-1}+0.606 \times 10^{-5} t^{2}$ & 0.9080 \\
6 & $J(t)=306.248+0.048 t-5.613 \sqrt{t}-361.600 t^{-1}-0.210 \times 10^{-4} t^{2}$ & 0.9446 \\
7 & $J(t)=643.843-0.044 t-12.035 \sqrt{t}+9.070 t^{-1}+0.503 \times 10^{-4} t^{2}$ & 0.9943 \\
8 & $J(t)=187.916-0.187 t+2.041 \sqrt{t}+123.911 t^{-1}+0.382 \times 10^{-4} t^{2}$ & 0.9874 \\
9 & $J(t)=430.882-0.147 t-6.031 \sqrt{t}-396.970 t^{-1}+0.353 \times 10^{-4} t^{2}$ & 0.9859 \\
10 & $J(t)=452.426-0.155 t-6.333 \sqrt{t}-416.820 t^{-1}+0.371 \times 10^{-4} t^{2}$ & 0.9860 \\
\hline
\end{tabular}


Table 2. Regression equation coefficients for responses

\begin{tabular}{lcccc}
\hline \multirow{2}{*}{ Parameter } & \multicolumn{2}{c}{ Average permeate flux $\mathrm{L} \mathrm{m}^{-2} \mathrm{~h}^{-1}$} & \multicolumn{2}{c}{ Permeate flux decline } \\
\cline { 2 - 4 } & Estimate & $p$-value & Estimate & $p$-value \\
\hline$b_{0}$ & Intercept & 0.0149 \\
\hline$b_{1}$ & 47.2501 & 0.6738 & 0.804370 \\
$b_{2}$ & Linear & 0.2261 \\
$b_{3}$ & 131.4139 & 0.0485 & -0.096996 & 0.2093 \\
\hline$b_{4}$ & -0.0061 & 0.9801 & -0.000567 & 0.7235 \\
$b_{5}$ & -5.6364 & 0.5393 & -0.004964 & 0.8973 \\
$b_{6}$ & & & 0.1389 \\
\hline
\end{tabular}

Table 3. Analysis of variance (ANOVA) of the modeled responses (J-average permeate flux; FD-permeate flux decline; DF - degree of freedom; SS - sum of squares, MS - mean squares)

\begin{tabular}{|c|c|c|c|c|c|c|c|c|c|}
\hline \multirow{3}{*}{ Response } & \multicolumn{9}{|c|}{ Source } \\
\hline & \multicolumn{3}{|c|}{ Residual } & \multicolumn{6}{|c|}{ Residual } \\
\hline & $D F$ & SS & $M S$ & $D F$ & SS & $M S$ & $F$-value & $p$-value & $R^{2}$ \\
\hline $\mathrm{J} / \mathrm{L} \mathrm{m}^{-2} \mathrm{~h}^{-1}$ & 3 & 5509.8 & 1836.5 & 7 & 633839.4 & 90548.5 & 49.3027 & 0.004290 & 0.9634 \\
\hline$F D$ & 3 & 0.013504 & 0.004501 & 7 & 4.161073 & 0.594439 & 132.0559 & 0.000995 & 0.9096 \\
\hline
\end{tabular}

values of $\mathrm{R}^{2}$, obtained for all responses indicated a good fit of experimental data to Eq. (2). All polynomial models tested for the selected responses were significant at $95 \%$ confidence level ( $p$-value: 0.05 , Table 3 ). The significance of each coefficient was determined through $p$-values. The smaller the magnitude of the $p$-value the more significant is the corresponding coefficient.

The closer the value of $R^{2}$ to the unity, the better the empirical model fits the actual data. The smaller the value of $R^{2}$, the less relevant the dependent variables in the model have to explain of the behavior variation [9].

As for the significance of the polynomial coefficients, its $p$-values suggest that the most important linear factor influencing average permeate flux is transmembrane pressure and the most important interaction is the interaction between transmembrane pressure and concentration.

The effects of transmembrane pressure and flow rate on average permeate flux are given in Figure 2. The average permeate flux is determined by values of initial and pseudo-steady-state permeate flux. At the beginning of the microfiltration process, the high initial fluxes over the first one and a half minutes allowed greater permeate throughout thus reduced processing time [10]. During the initial phase, the cross-flow velocity has little effect on deposit build-up [11]. This confirms the observations of several authors that the start of the process is governed by a purely frontal filtration rate [12]. This initial phenomenon is due to the large amount of particles deposited at the membrane surface. During this initial period, only a few particles are swept away because the permeate flux is perpendicular to the tangential flow. The pseudo-steady-state permeate flux, is, however, higher at the higher feed flow rate, which is in accordance with the film model [13], and it takes lesser time to achieve. The increase in flux values with an increase in the cross-flow velocities (CFV) can be explained with a thinner cake formed as a result of the higher forces carrying away particles from the membrane surface under higher CFV [14]. At the same time, the cake porosity increases by increasing cross-flow velocity, for micron particles [15]. As a result, the average permeate flux increases with flow rate, especially at higher TMP.

The influence of TMP on initial permeate flux is important and with the increase of TMP from 1 to 3 bar, the initial permeate flux increases for about 200\%, for all values of flow rate. This behavior is expected because the driven force for this process increases and, in the initial phase of microfiltration process, the cake layer is relatively thin and compressibility of the cake due to increasing TMP is not so prominent. The pseudo-state permeate flux increases with TMP, although the cake mass growth and its porosity decreases due to a higher filtration driving force [13]. At the maximum value of feed flow rate, the average permeate flux increases for about $200 \%$, with increase of TMP. 


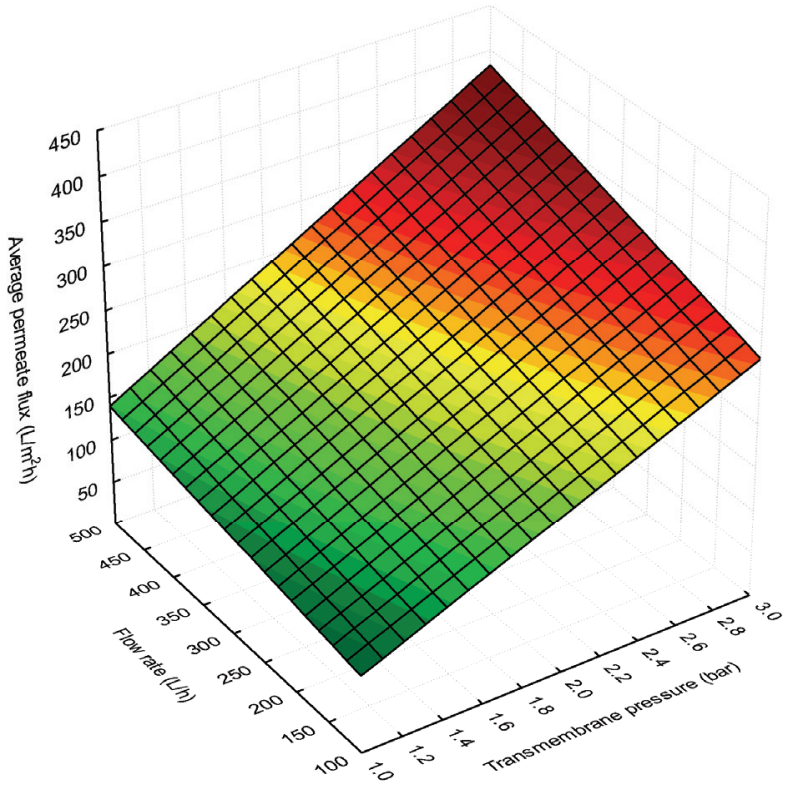

Figure 2. Effects of transmembrane pressure and flow rate on average permeate flux.

The effects of transmembrane pressure and concentration on average permeate flux are given in Figure 3. It can be seen that with the increase of concentration, flux rapidly decreases at all values of TMP used in experiments. The drop in average permeate flux values can be attributed to the increased resistance to flux flow due to the increased membrane fouling at a higher feed concentration, because more particles are available to foul the membrane. On the other hand, with increase of the transmembrane pressure, an increase in flux values was recorded at all feed concentrations. This increase is more evident at the lower suspension concentrations compared to the higher concentrations at which membrane surface is more fouled due to more available particles for membrane fouling.

The total particle mass in the cake layer is directly proportional to the permeate volume passing through the membrane, and the cake thickness is proportional to the total particle mass of the cake layer. The porosity tends to decrease with increasing transmembrane pressure. It indicates that a higher transmembrane pressure results in a denser and more compact cake layer [16]. Obviously, the spaces between particles in the cake layer never become completely closed, enabling the permeate to pass through.

The effects of flow rate and suspension concentration on average permeate flux are given in Figure 4. Increase in flow rate leads to an increase in average permeate flux at all values of concentration, but increased values of concentration lead to a decrease of average permeate flux. This effect is more obvious at higher concentrations and lower feed flow rates, because in that case the thickness of the cake layer grows rapidly on the membrane surface which results in small values of average permeate flux.

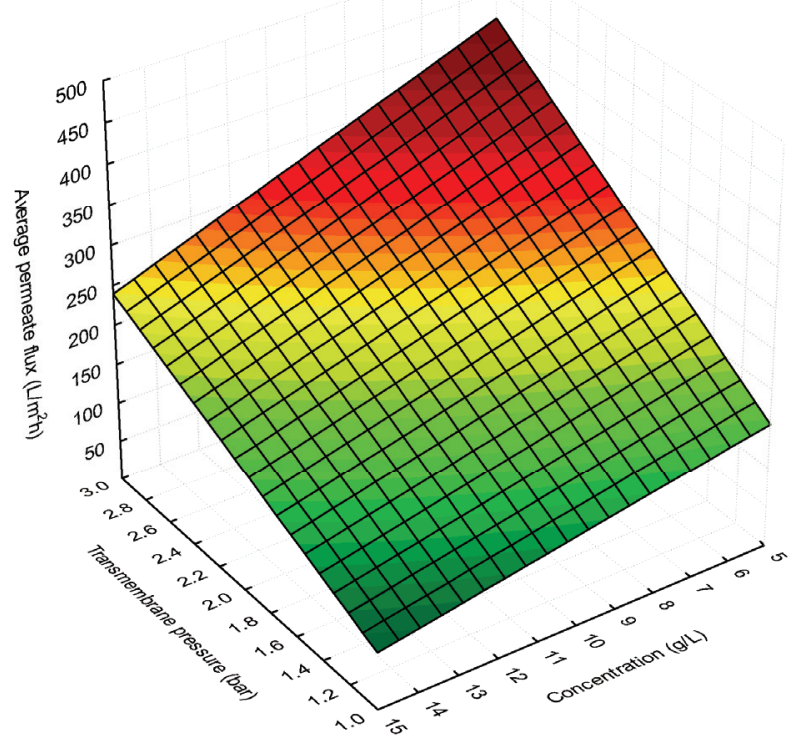

Figure 3. Effects of transmembrane pressure and suspension concentration on average permeate flux.

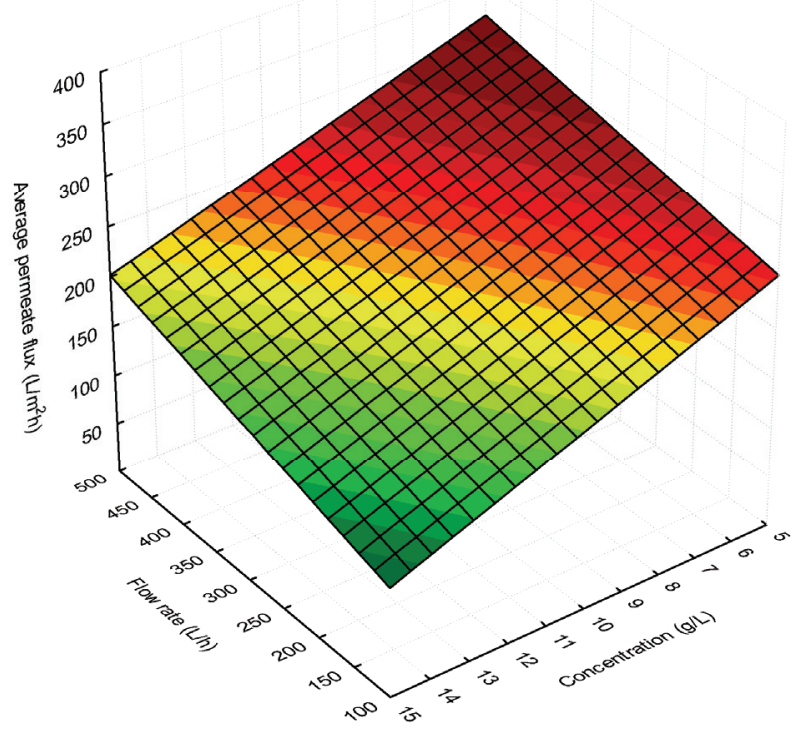

Figure 4. Effects of flow rate and suspension concentration on average permeate flux.

The largest influence on permeate flux decline comes from the interaction between transmembrane pressure and concentration, but that influence is not statistically significant. Varying parameter values within a specified range do not influence significantly the value of the permeate flux decline.

The effects of transmembrane pressure and flow rate on permeate flux decline are given in Figure 5. The 
value of permeate flux decline is almost constant with the increase of TMP at all values of flow rate. As expected, the increase in flow rate leads to a decrease of permeate flux decline. Flow rate does not have a major impact on the initial permeate flux, but it is very important after initial phase, during the process. At the highest values of flow rates, accumulation of starch particles on membrane surface is lesser, as well as membrane fouling.

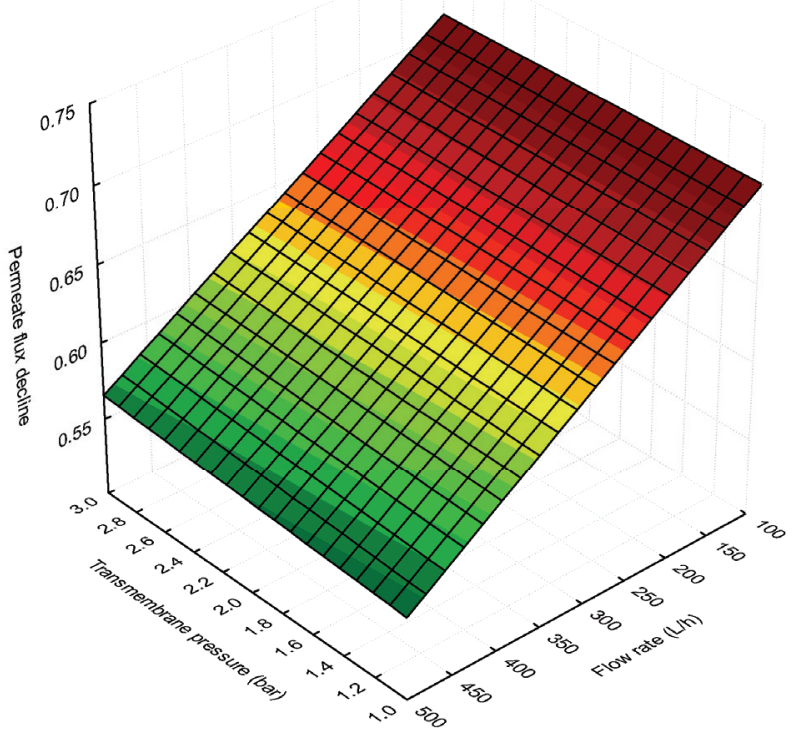

Figure 5. Effects of transmembrane pressure and flow rate on permeate flux decline.

The effects of TMP and concentration on permeate flux decline are given in Figure 6.

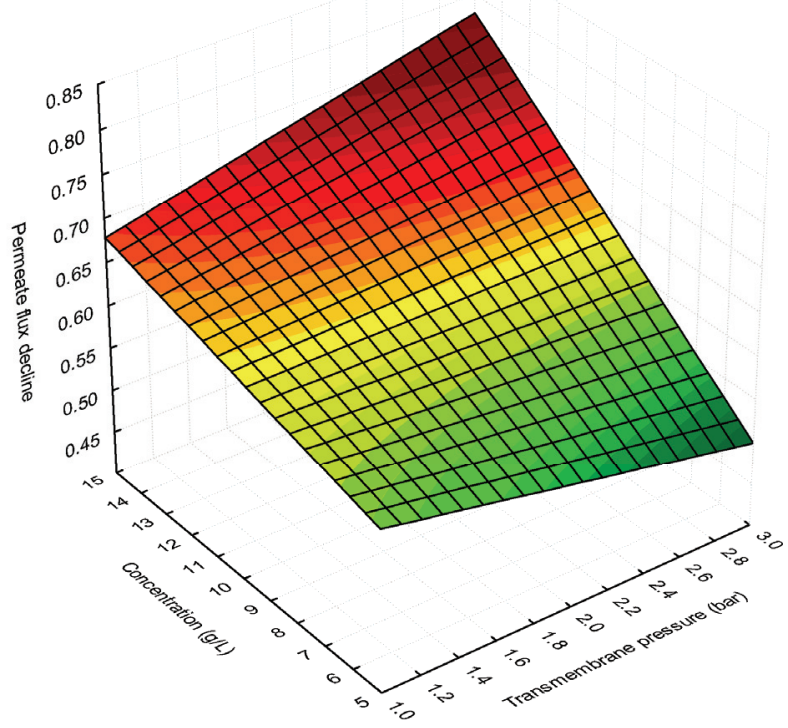

Figure 6. Effects of transmembrane pressure and suspension concentration on permeate flux decline.
Different behavior of the system can be noticed at higher and lower values of concentration with TMP change. At lower concentrations with TMP increase, permeate flux decline decreases, which is reasonable because the driving force for the microfiltration process increases. At higher values of concentration with the increase of TMP permeate flux decline increases. In this case the effect of membrane fouling is dominant and contamination is more pronounced. A higher TMP would result in a denser cake with a higher resistance. The theory suggests that microfiltration has no advantage when feed concentration is high, but the process should be run at lower values of transmembrane pressure, which leads to a higher permeate flux [14]. The difference between the largest and the smallest value of permeate flux decline is about $50 \%$ and the best conditions for minimum flux decline are maximum TMP and minimum concentration.

The effects of flow rate and concentration on permeate flux decline are given in Figure 7 . With the increase of flow rate permeate flux decline decreases at all concentrations. This effect is more apparent at lower values of concentration of starch suspension. With decrease of concentration, permeate flux decline increases at all values of flow rate. This effect is more obvious at higher values of flow rate. The best conditions for microfiltration process, observing the permeate flux decline, are minimum concentration and maximum flow rate. It can be concluded that the difference between the smallest and the largest flux decline is about $100 \%$ which cannot be negligible.

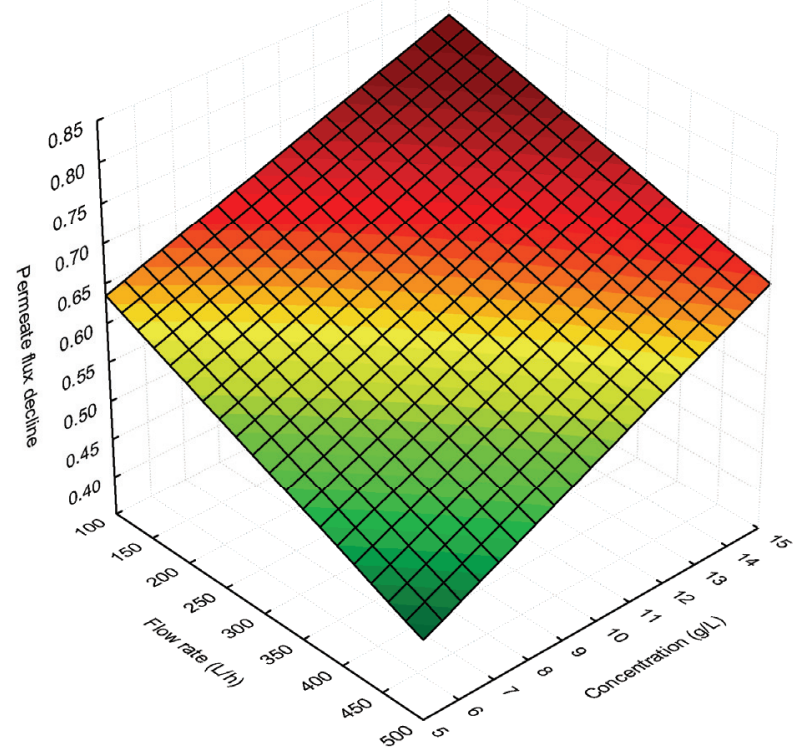

Figure 7. Effects of flow rate and suspension concentration on permeate flux decline.

\section{CONCLUSIONS}

The different conditions (transmembrane pressure, flow rate and suspension concentration) for the mic- 
rofiltration process of starch suspension revealed that all these variables markedly affect the average permeate flux, as well as the permeate flux decline. The results suggested that a polynomial model is adequate for representation of selected responses. Using surface plots, the optimum set of the operating variables are obtained graphically. The most significant linear factor is transmembrane pressure. Comparing the $p$-values, interaction between transmembrane pressure and suspension concentration is also important. The maximum value of the average permeate flux and minimum value of the permeate flux decline were reached for one combination of process parameters. The best combination was maximum transmembrane pressure (3 bar), maximum flow rate $(500 \mathrm{~L} / \mathrm{h})$ and minimum concentration ( $5 \mathrm{~g} / \mathrm{L})$. Theory suggests that, for this type of particles, permeate flux increases with TMP to the certain values of the equilibrium state. Further research is needed to focus on increasing TMP to determine the maximum value before the establishment of equilibrium state. It should be considered, also, whether a further increase in permeate flux with increasing TMP is justified from an economic point of view.

\section{Acknowledgements}

The authors wish to express their sincere gratitude to the Ministry of Science and Technological Development of the Republic of Serbia for its financial support (Project Number: TR-31002).

\section{REFERENCES}

[1] D.R. Kent, Front End to Backpipe: Membrane technology in the starch processing industry, Starch/Stärke 54 (2002) 273-284.

[2] E. Drioli, M. Romano, Progress and New Perspectives on Integrated Membrane Operations for Sustainable Industrial Growth, Ing. Eng. Chem. Res. 40 (2001) 1277-1300.

[3] S. Ripperger, J. Altmann, Crossflow microfiltration - state of the art, Sep. Purif. Technol. 26 (2002) 19-31.

[4] R. Shukla, R. Tandon, M. Nguyen, M. Cheryan, Microfiltration of starch suspensions using a tubular stainless steel membrane, Membr. Technol. 120 (2000) 5-8.
[5] A. Hinkova, Z. Bubnik, V. Pour, S. Henke, P. Kadlec, Application of cross-flow ultrafiltration on inorganic membranes in purification of food materials, Czech J. Food Sci. 23 (2005) 103-110.

[6] B. Cancino, F. Rossier, C. Orellana, Corn starch waste water treatment with membrane technologies: pilot test, Desalination 200 (2006) 750-751.

[7] M.-C. Martí-Calatayud, M.-C. Vincent-Vela, S. ÁlvarezBlanco, J. Lora-García, E. Bergantiños-Rodríguez, Analysis and optimization of the influence of operating conditions in the ultrafiltration of macromolecules using a response surface methodological approach, Chem. Eng. J. 156 (2010) 337-346.

[8] C. Cojocaru, G. Zakrzewska-Trznadel, Response surface modeling and optimization of copper removal from aqua solutions using polymer assisted ultrafiltration, J. Membr. Sci. 298 (2007) 56-70.

[9] W.C. Lee, S. Yusof, N.S.A. Hamid, B.S. Baharin, Optimizing conditions for enzymatic clarification of banana juice using response surface methodology (RSM), J. Food Eng. 73 (2006) 55-63.

[10] G. Russotti, A.E. Osawa, R.D. Sitrin, B.C. Buckland, W.R. Adams, S.S. Lee, Pilot-scale harvest of recombinant yeast employing microfiltration: a case study, J. Biotechnol. 42 (1995) 235-246.

[11] M. Hamachi, M. Mietton-Peuchot, Experimental investigations of cake characteristics in crossflow microfiltration, Chem. Eng. Sci. 54 (1999) 4023-4030.

[12] M. Hamachi, M. Mietton-Peuchot, Analysis of deposit behaviour in cross-flow microfiltration by means of thickness measurement, Chem. Eng. J. 86 (2002) 251$-257$.

[13] G.T. Vladisavljević, P. Vukosavljević, B. Bukvić, Permeate flux and fouling resistance in ultrafiltration of depectinized apple juice using ceramic membranes, J. Food Eng. 60 (2003) 241-247.

[14] O.O. Ogunbiyi, N.J. Miles, N. Hilal, The effects of performance and cleaning cycles of new tubular ceramic microfiltration membrane fouled with a model yeast suspension, Desalination 220 (2008) 273-289.

[15] K.J. Hwang, Y.L. Hsu, K.L. Tung, Effect of particle size on the performance of cross-flow microfiltration, Adv. Powder Technol. 17 (2006) 189-206.

[16] Y. Lee, M.M. Clark, Modeling of flux decline during cross-flow ultrafiltration of colloidal suspensions, J. Membr. Sci. 149 (1998) 181-202. 


\section{IZVOD}

\section{PRIMENA VIŠEKANALNE KERAMIČKE MEMBRANE U MIKROFILTRACIJI SUSPENZIJA SKROBA}

Bojana B. Ikonić ${ }^{1}$, Zoltan Z. Zavargo ${ }^{1}$, Aleksandar I. Jokić ${ }^{1}$, Zita I. Šereš ${ }^{1}$, Gyula N. Vatai ${ }^{2}$, Mihailo B. Peruničić ${ }^{1}$

${ }^{1}$ Tehnološki fakultet, Univerzitet u Novom Sadu, Novi Sad, Srbija

${ }^{2}$ Fakultet za prehrambene tehnologije, Corvinus Univerzitet u Budimpešti, Budimpešta, Mađarska

(Naučni rad)

Fabrike skroba su suočene sa sve rigoroznijim zakonskim regulativama vezanim za zaštitu životne sredine, kao i sve većim troškovima prerade otpadnih voda i njihovog skladištenja. Inovativno rešenje u procesu prerade otpadne vode predstavlja primena membranskih separacionih procesa. Membrane imaju sposobnost da postignu odgovarajući stepen separacije bez upotrebe toplote i na taj način poboljšavaju kvalitet samog proizvoda i smanje troškove prerade. Ideja je da se otpadni tok podvrgne mikrofiltraciji, pri čemu se kao permeat dobija prečišćena otpadna voda koja se može ponovo koristiti u tehnološkom procesu, a kao koncentrat suspenzija sa visokim sadržajem skroba koji se može regenerisati. Cilj ovog rada je ispitivanje mikrofiltracije model suspenzija pšeničnog skroba na višekanalnoj keramičkoj membrani sa prečnikom pora 200 nm, kao i mogućnosti primene postupka odzivne površine za modelovanje. Primenom pomenute membrane je moguće skoro u potpunosti izdvojiti čestice skroba iz suspenzije tokom koncentrisanja (99-99,9\%). U procesu mikrofiltracije varirane su vrednosti tri parametra (transmembranski pritisak, protok retentata i koncentracija suspenzije) i ispitivan je njihov uticaj na srednji fluks permeta, kao i na pad fluksa. Eksperimentalni rezultati promene fluksa permeata mogu se na adekvatan način aproksimirati polinomom drugog stepena. Visoke vrednosti koeficijenta determinacije za oba posmatrana odziva $(0,9634$ za srednji fluks permeata i 0,9096 za pad fluksa permeata) ukazuju na opravdanost ovog pristupa. Statistička mera značajnosti svakog od regresionih koeficijenata je njegova $p$-vrednost. Najveći uticaj na vrednosti srednjeg fluksa permeata ima transmembranski pritisak, dok je uticaj protoka na vrednost pada fluksa značajna, ali ne statistički. Povećanje transmembranskog pritiska od 1 do 3 bara dovodi do povećanja srednjeg fluksa oko $200 \%$, dok se pad fluksa ne menja značajno sa promenom TMP. Povećanje protoka suspenzije od 100 do 500 L/h utiče na povećanje srednjeg fluksa permeata za 40-100\% i na smanjenje pada fluksa oko 40\%. Povećanje koncentracije napojne suspenzije dovodi do pada srednjeg fluksa permeata za 40-100\% i na povećanje pada fluksa od 20-50\%. Optimalni uslovi za proces mikrofiltracije suspenzije skroba tokom njenog koncentrisanja su maksimalna vrednost transmembranskog pritiska (3 bara), maksimalna vrednost protoka $(500 \mathrm{~L} / \mathrm{h})$ i minimalna koncentracija (5 g/L), gde su vrednosti srednjeg fluksa permeata $430 \mathrm{~L} \mathrm{~m}^{-2} \mathrm{~h}^{-1}$, a pad fluksa 0,4 .
Ključne reči: Cross-flow mikrofiltracija • Suspenzija skroba • Potpun faktorijalni plan • Postupak odzivne površine 